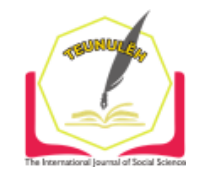

Jurnal Ilmiah Teunuleh

The International Journal of Social Sciences

Vol. 2, Issue. 2, June 2021

E-ISSN: $2746-4393$

\title{
CURRICULUM CONCEPT AT THE LEVEL OF EDUCATION UNIT
}

\author{
Aidil Saputra \\ STAIN Teungku di Rundeng Meulaboh \\ aidilmbo@gmail.com
}

\begin{abstract}
Abtrack
The education unit level curriculum (KTSP) is the latest curriculum in Indonesia that is recommended to be used as a reference by curriculum developers at the education unit level. KTSP is a curriculum oriented towards the achievement of co-existence, therefore this curriculum is an improvement of the curriculum based on co-existence. The Education Unit Level Curriculum (KTSP) which was implemented gradually starting in 2006 gives teachers and schools (Educational Unit Level Institutions) the flexibility to develop it. Teachers and schools are given the freedom to create by relying on content standards, graduation standards, and curriculum preparation guidelines set by the government (c.q. National Standards Agency for Education). Curriculum Level Education Unit, born from the spirit of regional autonomy, where education affairs are not all central responsibility, but partly the responsibility of the region, therefore judging by the pattern or model of development KTSP is one of the models of curriculum that is desentralistic. The nature of KTSP itself includes the understanding, purpose, basis or foundation of development, principles of development and components of KTSP.
\end{abstract}

Keywords: Curriculum, Level and Unit, Learning.

\section{A. Introduction}

Education is a conscious and planned effort, processing learning so that students actively develop their potential to have religious spiritual strength, self-control, personality, intelligence, noble character, skills carried out by themselves, society, nation and state. (Pendidikan, Undang-Undang Republik Indonesia, No. 20 Tahun 2003, Tentang Sistem Pendidikan Nasional, 2003, p. 3). Education in Islam is defined as guidance given by someone to someone so that he develops optimally in accordance with Islamic teachings (Tafsir, 2005, p. 32) Islamic religious education as an effort to educate Islam or Islamic teachings and values, so that it becomes the way of life (views and attitudes of 
life) of students. (Muhaimin, 2005, pp. 7-8). In addition, the application of education cannot be separated from teachers, students, and curriculum. To produce education as expected.

\section{B. Method}

This type of research is a literature study (library research). metThe ode used in this study is a qualitative approach. Data collection techniques in this study used observation, interviews, and documentation studies which were then analyzed and presented so that they had meaning.

Miles and Huberman (1992:20) suggest that the approach in qualitative data analysis consists of data reduction, "display" data, drawing conclusions and verification. Thus, researchers perform data reduction continuously during the analysis. Then proceed with the data display to see the overall picture of the research results, both in the form of a matrix and in the form of coding. And finally, the researcher draws conclusions and verifies so that the data is meaningful.

\section{Discussion}

1. Understanding KTSP

KTSP is legally mandated by Law Number 20 of 2003 concerning the National Education System and Government Regulation of the Republic of Indonesia Number 19 of 2005 concerning National Education. The preparation of the KTSP by schools began in the 2007/2008 school year by referring to the Content Standards (SI) and Graduate Competency Standards (SKL) for primary and secondary education as issued through the Regulations of the Minister of National Education Number 22 of 2006 and Number 23 of respectively 2006, as well as guidelines for the development of KTSP issued by BSPN. (Pendidikan, Wikipedia Indonesia, 2021)

In the National Education Standards (SPN Article 1, Paragraph 15), it is explained that the Education Unit Level Curriculum (KTSP) is an operational curriculum that is prepared and implemented by each education unit. The preparation of the KTSP is carried out by the education unit by taking into account and based on competency standards and basic competencies developed by the National Education Standards Agency (BSNP). (Sanjaya, 2008, p. 128).

Curriculum is a set of plans and arrangements regarding the objectives of the content and learning materials as well as the methods used as guidelines for the 
implementation of learning activities to achieve certain educational goals, including national education goals and conformity with the peculiarities, conditions and potential of regions, educational units and students. Therefore, the curriculum is prepared by the education unit to allow the adjustment of educational programs to the needs and potentials that exist in the region.

KTSP is an operational curriculum compiled by and implemented in each educational unit. KTSP consists of educational objectives at the level of the education unit, the structure and content of the KTSP, educational calendar, syllabus.

When we analyze the concept above, there are several things related to the meaning of the operational curriculum. First, as an operational curriculum, it is in development. KTSP will not be separated from the provisions that have been prepared by the government nationally. That is, even though the regions are given the authority to develop the curriculum, the authority is only limited to operational development, while the reference for development itself is determined by the government, for example the types of subjects and the number of hours of lessons, the content of each subject itself, and competencies. that each subject must achieve.

Second, As an operational curriculum, KTSP developers are required and must pay attention to regional characteristics, in accordance with the sound of Law No. 20 of 2003 paragraph 2, namely that the curriculum at all levels and types of education is developed according to the principles of education level, regional potential, and students. This issue is important to understand, because although this standard is determined by the government, in the operational learning that is planned and carried out by teachers and curriculum developers, it is inseparable from regional conditions and conditions.

Third, as an operational curriculum, curriculum developers become learning units, for example in developing learning strategies and methods, in determining learning media, in determining evaluations to be carried out including in determining several meetings and when all material topics must be studied by students so that the basic competencies that done can be achieved (Sanjaya, 2008, p. 129).

\section{KTSP Characteristics}

As a concept, as well as a program, KTSP has the following characteristics (Kunandar, 2008, p. 138):

a. KTSP emphasizes the achievement of student competencies in the individual and classical Education Unit Level curriculum. In KTSP students are formed to 
develop knowledge, understanding, abilities, values, attitudes and interests which will eventually form a skilled and independent person.

b. KTSP is oriented towards learning outcomes and diversity.

c. Delivery in learning uses a variety of approaches and methods.

d. The sources are not only teachers, but other learning resources that fulfill educational elements. Assessment emphasizes the process and learning outcomes in an effort to master or achieve a competency.

A competence that is expected to be achieved by students includes aspects of thinking, skills and personality. The main purpose of competency standards is to provide direction to educators about the abilities and skills that are the focus of the learning and assessment process. So, competency standards are the limits and directions of abilities that must be possessed and can be done by students after following the learning process of a particular subject (Kunandar, 2008, p. 139).

\section{Purpose of KTSP}

In general, the purpose of implementing the KTSP is to become independent and empower educational units through the granting of authority (autonomy) to educational institutions. Thus, through KTSP it is hoped that it can encourage schools to make participatory decision-making by developing a curriculum (Sanjaya, 2008, p. 132).

In accordance with its autonomy, the KTSP provides an opportunity for schools to actively participate in developing the curriculum, thus, the curriculum developed in each educational unit will be more meaningful to prepare students to become members of the community that are useful in developing their regional potential.

Specifically, the objectives of implementing the KTSP are to:

a. Improving the quality of education through independence and school initiatives and developing curricula, managing, and empowering available resources.

b. Increase the awareness of school members and the community in curriculum development through joint decision making.

c. Improving healthy competence among educational units regarding the quality of education to be achieved.

Efforts Educational Goals at the Education Unit Level The educational objectives at the primary and secondary education levels are formulated referring to the following general educational objectives. 
1. The purpose of basic education is to lay the foundation for intelligence, knowledge, personality, noble character, and skills to live independently and participate in further education.

2. The purpose of secondary education is to increase intelligence, knowledge, personality, noble character, and skills to live independently and participate in further education.

3. The purpose of vocational secondary education is to increase intelligence, knowledge, personality, noble character, and skills to live independently and to participate in further education in accordance with their profession.

Educators must be able to create and design a learning environment by combining various experiences around their environment, including social, cultural, physical and psychological environments in order to achieve their learning goals. These efforts can provide certain benefits, both for teachers and students. Nana Syaodih Sukmadinata identified 4 (four) benefits of learning objectives, namely:

1. Make it easier to communicate the intent of teaching and learning activities to students, so that students can carry out their learning actions more independently.

2. Makes it easier for teachers to choose and arrange teaching materials.

3. Help make it easier for teachers to determine learning activities and learning media.

4. Make it easier for teachers to make assessments (Sukmadinata, 2002, p. 48).

\section{Principles of KTSP Development and Implementation}

In the guide to the preparation of the KTSP for basic and secondary education compiled by the 2006 BSNP, it is stated that the KTSP is developed according to its relevance by each educational group or unit under the coordination and supervision of the education office or the Regency/City Ministry of Religion office for basic education and the province for secondary education.

The principles of KTSP development are as follows (Muhaimin dkk, 2008, p. 21):

a. Centered on the potential, development, needs, or interests of students and their environment. The curriculum is developed based on the principle that students have a central position to develop competence in order to become human beings who believe and are devoted to God Almighty,

b. Diverse and integrated. The curriculum is developed by taking into account the diversity of student characteristics, regional conditions, levels and types of education, 
as well as respecting and not discriminating against differences in religion, ethnicity, culture, customs, social status, economy, and gender.

c. Respond to the development of science, technology and art. The curriculum is developed on the basis of the awareness that science, technology and arts are developing dynamically.

d. Relevant to the needs of life. Curriculum development is carried out by involving stakeholders to ensure the relevance of education to the needs of life, including community life, the business world and the world of work.

e. Comprehensive and sustainable. The substance of the curriculum includes all dimensions of competence, scientific studies and subjects that are planned and presented on an ongoing basis between all levels of education.

f. Lifelong learning. The curriculum is directed to the process of developing, cultivating, and empowering learners that lasts a lifetime.

g. Balance between national interests and regional interests. The curriculum is developed by taking into account national and regional interests to build the life of society, nation and state.

The principles for implementing the KTSP are as follows (Muhaimin dkk, 2008, p. 23):

a. Based on the potential, development and conditions of students to master useful competencies for themselves. In this case, students must get services.

b. Upholding the five pillars of learning, namely: first, learning to have faith and fear of God Almighty, second, learning to understand and appreciate, third, learning to implement and being able to implement and act effectively, fourth, learning to live together and be useful to others, and fifth, learning to build and find identity, through a learning process that is active, creative, effective, and fun.

c. The possibility of students getting services that are repair, enrichment, and acceleration in accordance with the potential, developmental stage, and condition of students while still paying attention to the integration of students' personal development with divine, individual, social, and moral dimensions.

d. It is carried out in an atmosphere of a relationship between students and educators who accept and respect each other, are friendly, open, and warm, with the principles of tut turihandayani, ing media manganese, ing karsa sang adada.

e. It is carried out by utilizing natural, social and cultural conditions as well as regional wealth for the success of education with the contents of all study materials optimally. 
f. Covering all components of subject competence, local content and self-development carried out in a balance, linkage, and continuity that is suitable and adequate between classes and types and levels of education.

\section{KTSP Manufacturing and Development Procedure}

As a curriculum plan, it must be made based on various conditions. That is why the process of curriculum creation and development is a continuous chain process between one process and another. The curriculum as a plan is essentially an effort to produce graduates, or change the input of students from initial conditions to students who have competence.

The competency of the graduate in question has criteria;

1. Able to understand the concepts that underlie the competency standards that must be mastered/achieved.

2. Able to do work in accordance with the demands of competency standards that must be achieved with the right procedures and good results.

3. Able to apply his abilities in everyday life (inside and outside school).

Thus, competence is a good combination of knowledge, skills in carrying out work (skills), and attitudes required to master a job (attitude). (Muhaimin, 2005, p. 24).

\section{KTSP Components}

KTSP has four components, namely (1) educational goals at the level of the education unit, (2) the structure of the content of the KTSP, (3) the educational calendar, and (4) the syllabus and teaching plan (RPP). (Muslich, 2007, p. 12).

a. Educational Objectives at the Education Unit Level.

The formulation of educational goals at the education unit level refers to the following general educational objectives:

- The purpose of basic education is to lay the foundation for intelligence, knowledge, personality, noble character, and skills to live independently and attend further education.

- The purpose of secondary education is to increase intelligence, knowledge, personality, noble character, and skills to live independently and attend further education. 
- The purpose of vocational secondary education is to increase intelligence, knowledge, personality, noble character, and skills to live independently and follow further education in accordance with the vocational.

b. Content Structure of Education Unit Level Curriculum.

The structure of the Education Unit Level Curriculum at the primary and secondary education levels is contained in the Content Standards, which were developed from the following subject groups:

- Group of religious subjects and noble character.

- Citizenship and personality subject groups.

- Group of science and technology subjects.

- Esterika subject group.

- Group of physical subjects, sports, and health.

The subject groups are carried out through learning content or activities as described in PP No.19 of 2005 concerning National Education Standards, article 7.

The curriculum content at the education unit level includes a number of subjects whose breadth and depth is a learning burden for students in the education unit. In addition, local content materials and self-development activities are included in the curriculum content.

c. Education calendar.

The education unit can compile an educational calendar in accordance with regional needs, school characteristics, the needs of students and the community by taking into account what is stated in the Content Standards.

d. Syllabus and lesson plans.

The syllabus is an elaboration of competency standards and basic competencies into subject matter, learning activities, and competency achievement indicators for assessment based on this syllabus, the teacher can develop into a learning implementation plan (RPP) that will be determined in teaching and learning activities (KBM) for students.

\section{KTSP Advantages and Weaknesses}

KTSP too. Competency-Based Curriculum (KBK) has various advantages and disadvantages. The advantages of this concept, although not the only format to anticipate educational problems, but in general, KTSP can be "reliable" as a benchmark for facing future challenges by providing skills to students. Another advantage, KTSP has 
Curriculum Concept at The Level of Education Unit

the ability to adapt to the region, local, because the skills taught are based on the environment and the ability of students. In addition, there is also an award for individual students. Students who are able to absorb material quickly will be given additional material as enrichment, and students who are lacking will be handled by the teacher with great patience by repeating the material or giving remedial. Students are also invited to talk, discuss, interviews and discussing contextual problems, which in reality are needed so that students become more understanding and animating the problems because they are in accordance with the circumstances of students in everyday life. Participant. Students are not only required to memorize but what is more important is learning the process so as to encourage students to research and apply it in everyday life.

However, the difficulty that may arise from the implementation of this KTSP is the need for sufficient time by educators in fostering the development of their students, especially students with below average abilities. The fact proves that the social and economic conditions that suppress the welfare of teachers' lives, cause them to concentrate less in the learning process. Not to mention considering the uneven quality of teachers in each region. This means, KTSP faces constraints on the power of creativity and the various capacities of teachers to create. own curriculum.Learning problems are certain conditions experienced by students and hinder the smooth process carried out by individuals to obtain a new behavior change as a whole (Partowisastro, 1986, p. 92).

Another obstacle, KTSP demands the ability of teachers to carry out competencybased learning by planning for themselves how the right strategy is applied according to the conditions and abilities of the local area. In addition to the problem of educational facilities in schools which are still very minimal. In fact, this concept is more focused on practice in the field in accordance with the competencies possessed rather than theory alone. Another obstacle experienced by teachers is the lack of understanding of what and how to evaluate with a portfolio. Because of this misunderstanding, they return to the old assessment pattern with only cognitive-based tests and tests. The absence of a school model that can be used as a reference makes teachers unable to make changes, let alone jumps, in the process of improving teaching learning activities.

With regard to the absence of material targets in the KTSP, on the one hand, the KTSP emphasizes the competence of students, which means that the learning process must be considered by the teacher, on the other hand, the material, although not prioritized, must be completed in the end. Thus the teacher must race against time, while the success of the learning process cannot be ascertained. This has an impact on the low 
learning outcomes of the students he fosters, which leads to the rejection of the government's policy on the National Examination (UN) as the basis for determining the graduation of students.

\section{Conclusion}

The education unit level curriculum (KTSP) is the latest curriculum in Indonesia which is recommended to be used as a reference by curriculum developers at the education unit level.

The curriculum was born from the spirit of regional autonomy, where education matters are not all the responsibility of the center. However, some are the responsibility of the region. Therefore, judging from the pattern or model of development, this curriculum is one of the decentralized curriculum models.

Therefore, with the implementation of the KTSP curriculum, we hope that in the future it will give birth to a better quality of education than before, so that what has been formulated from the educational goals itself can be fully achieved.

\section{Bibliography}

Kunandar. (2008). Guru Profesional: Impelementasi Kurikulum Tingkat Satuan Pendidikan (KTSP) dan Sukses dalam Sertifikasi Guru. Jakarta: Raja Grafindo Persada.

Muhaimin. (2005). Pengembangan Kurikulum Pendidikan Agama Islam. Jakarta: Raja Grafindo Persada.

Muhaimin dkk. (2008). Pengembangan Model Kurikulum Tingkat Satuan Pendidikan (KTSP) pada Sekolah dan Madrasah. Jakarta: Raja Grafindo Persada.

Muslich, M. (2007). KTSP (Kurikulum Tingkat Satuan Pendidikan). Jakarta: Bumi Aksara.

Partowisastro. (1986). Diagnosa dan Pemecahan Kesulitan Belajar, . Jakarta: Erlangga.

Pendidikan, D. (2003). Undang-Undang Republik Indonesia, No. 20 Tahun 2003, Tentang Sistem Pendidikan Nasional. Bandung: Citra Umbara.

Pendidikan, D. (2021, Mei 11). Wikipedia Indonesia. Retrieved from Kurikulum Tingkat Satuan Pendidikan: https://id.wikipedia.org/wiki/

Sanjaya, W. (2008). Kurikulum dan Pembelajaran: Teori dan Praktik Pengembangan Kurikulum Tingkat Satuan Pendidikan (KTSP), . Jakarta: Kencana. 
Curriculum Concept at The Level of Education Unit

Sukmadinata, N. S. (2002). Pengembangan Kurikulum: Teori dan Praktek. Bandung: Remaja Rosdakarya.

Tafsir, A. (2005). IImu Pendidikan Dalam Perspektif Islam, Cet. VI, (Bandung: Remaja Rosda Karya, 2005), h. 32. Bandung: Remaja Rosda Karya. 